\title{
MITIGATING NATURAL DISASTER IN THE MIDST OF LIMITATIONS: HUMAN SECURITY ISSUES IN OVERCOMING THREAT OF FLOOD IN CITARUM RIVER BASIN, INDONESIA \\ Arry Bainus ${ }^{1 *}$, Dina Yulianti ${ }^{2}$, Luthfi Hamzah Husin ${ }^{3}$ \\ ${ }^{1 * 2}$ Department of International Relations, Universitas Padjadjaran, Bandung, Indonesia; ${ }^{3}$ Department of Political Science, Universitas Padjadjaran, Bandung, Indonesia. \\ Email: ${ }^{1 *}$ arrybainus@unpad.ac.id, ${ }^{2}$ dina14@unpad.ac.id, ${ }^{3}$ 1.h.husin@unpad.ac.id
}

Article History: Received on $28^{\text {th }}$ January 2020, Revised on $15^{\text {th }}$ April 2020, Published on $15^{\text {th }}$ June 2020

Abstract

Purpose: The article aims to analyze human security issues in the Citarum river basin, Indonesia, by taking the threat of flood in the Majalaya District as a case study. As the case has been increasing in recent years, wave the flood has become an inevitable source of fear for people living in the Citarum river basin in the rainy season. Environmental pollution due to massive industrialization, land function change, especially in the upstream area, and the absence of proper disaster mitigation from local government are problematized in this research.

Methodology: Using the Human Security point of view, the article tries to show people's perspectives in defining security and overcoming threats, especially relating to flood in the Citarum river basin. As for the method, the research uses a qualitative approach with a study case as an analytical strategy. We interviewed some informants who live in Majalaya District and found secondary data from the government's and society's documents and analyze it by using the Human Security approach.

Principal Findings: This article shows how the society's recognition and feeling on the environmental threat and organizes a limited community-based disaster mitigation system, which is called the 'JagaBalai' community, as an effort to build internal resilience and to overcome the risk and fear coming from the flood.

Implications/Applications: The findings of this research contribute to the literature on Human Security concerns, especially those related to its elements of freedom of fear related to natural disasters or any other environmental issues.

Novelty/Originality of this study: The current study fills the gap in the existing body of literature by analyzing the dynamics between an individual's perspective and the state as a source of security in the Majalaya District, Indonesia, by using Human Security approach. This approach can be useful to describe the degree of disaster victims' perceptions of fear and security and their relationship to government policies.

Keywords: Citarum River, Flood, Human Security, Mitigation, Natural Disaster.

\section{INTRODUCTION}

Majalaya, as a district located on the banks of the Citarum River, Indonesia, is one area with a high level of flood hazard. Besides being named the world's dirtiest and the most polluted river by several international media (Aljazeera, 2018; The Diplomat, 2018), Citarum river basin also has other problems in the form of the threat of flash floods that often occur in the rainy season. One of the worst disasters occurred in early 2018, where Majalaya and two surrounding districts were hit by flash floods with an average water level reaching over two meters (Detiknews, 2018). Thousands of people's houses were damaged or submerged due to the disaster, including several free community facilities such as schools, offices, and health centres. Damage that mostly occurred in the homes of residents who live close to the river flow due to the strong current of flash floods that could damage the walls of the house. In addition to material losses, several fatalities were recorded due to illness in the refugee camp.

According to the Indonesian National Disaster Management Agency (Badan Nasional Penanggulangan Bencana or BNPB), in residents on the banks of the Citarum River, especially in the areas of Baleendah District and Majalaya District, Bandung Regency, could experience flooding ten times (Kontan.co.id, 2019). The intensity and high rainfall but briefly coupled with environmental damage in the upstream sector and silting of rivers cause the risk of flash floods, or sudden flooding. In the last flood event at the beginning of 2019, BNPB noted an increase in the number of affected victims, namely a total of 22,105 families, with a total of 90 displaced families or around 283 people (Kompas.com, 2019).

In terms of Human Security, floods that often occur in Majalaya are causing material and fatalities, and accordingly, they can be categorized as a source of threats to humans. One important dimension of Human Security, namely freedom of fear, is important to look at because of the threat of fear that consistently haunts citizens. This is also exacerbated by the criticism that a government that should be a source of security fails to conduct proper disaster mitigation. Therefore, the threat of flash floods caused mainly by environmental destruction in the upstream, land-use change, and environmental pollution cannot be addressed properly. 
One of the previous studies has been carried out by Jimba, Hubbard, Sase, Suzuki, \&Otsuka (2011), who research a comparative study of social security issues on disaster rehabilitation in Haiti and Japan. This research shows that the Human Security approach in terms of disaster studies should not only look at a people-centered perspective but also more specifically looks at the more vulnerable people who are victims of the disaster. These vulnerable people, according to their research, have to be assisted so that they can get back their physical and emotional resilience against the threats that occur due to disasters. This research, however, lacks discussion about the relation and dynamics between the perspective of individual and state as a source of security. As argued by Sato (2010), who researches the disaster recovery of the 2004 tsunami in Thailand, human security issues are highly influenced by locality and identity so that Human Security approach must also consider the structure and local authority, such as local governments, local NGOs, etc. Furthermore, another study conducted by Bambals (2015), which uses Human Security as a tool in understanding flood disasters in Orge, Latvia, argues that although Human Security is, in fact, and underdog (minor) concept in security studies, it is sufficient and beneficial to help formulate security issues by dissecting Human Security and individual perspectives in two dimensions: objective and subjective. Using survey methods, Bambals (2015) shows that the Human Security approach can be used as a tool to effectively describe the extent of disaster victims' perceptions of fear and security and their relationship to government policies.

Drawing on these studies, this article aims to analyze the dynamics between an individual's perspective and the state as a source of security in the Majalaya District, Indonesia, by using the Human Security approach. Specifically, this study to achieve objectives:

1. Aims to analyse the dynamics between an individual's perspective and the state as a source of security in the Majalaya District, Indonesia, by using the Human Security approach.

2. To describe the ways and effort to build internal resilience and to overcome the risk and fear coming from the flood.

3. To analyse how effectively the human security approach can be useful to describe the degree of disaster victims' perceptions of fear and security and their relationship to government policies.

\section{LITERATURE REVIEW}

\section{Human Security Approach and the Threat of Natural Disaster}

A research team from the Bandung Institute of Technology has previously researched the application of early warning systems developed by the community in Majalaya. Together with the "Garda Cash" community (another name for "JagaBalai"), they built a weather prediction system in the form of an "automatic hydro-meteorological observation system" and "automatic heavy rain warning system". Although based on technology, the operation of this early warning system still relies on the involvement of local communities (Junnaedhiet al., 2017). Another study conducted by Hassani (2016) concluded that Majalaya District has a high level of flood threat and vulnerability, but the communities in the region do not have disaster management capacity, including disaster preparedness. Meanwhile, this article will describe the movement of the JagaBalai community in implementing the flood early warning system (FEWS) using a Human Security perspective.

Human Security is a non-traditional security concept that is concerned with security at the individual level. In the concept of traditional security, security is viewed from the perspective of the state. The state is considered safe if it succeeded in protecting its sovereignty territory from outside attacks. Security is defined as the absence of war, and this is related to the military. Meanwhile, in the concept of Human Security, individuals in the country receive special attention, where they are seen as entitled to security from various aspects, ranging from the economy to human rights (Wibowo, \&Zamzamy, 2015; Martin \& Owen, 2014; Sriboonyaponrat, 2016).

United Nations Development Programme (UNDP) (1994), in its Human Development Report, mentioned two main components of Human Security, namely 'freedom from fear' and 'freedom from want'. It mentioned seven categories of human Security, namely economic security, food security, health security, environmental security, personal security, community security, and political security. There are two schools of thought regarding this concept. Japan school, which is one of the thought that actively raises the Human Security narrative in the international arena, places more emphasis on the aspect of "freedom from want", and on this basis, Japan school has supported various development programs in poor and developing countries. In contrast, Canada's school brings a perspective that is more focused on "freedom from fear", which provides support efforts to citizens who fail to be protected by the state. This perspective then developed into the concept of the Right to Protect (R2P), which justifies the international community to intervene in a country's internal affairs to protect civilians in the country who experience insecurity from various causes such as violence and domestic conflict. (Jimba, et al, 2011; Pitsuwan\& Caballero-Anthony, 2014).

Through the formation of the Human Security Commission in 2001 by the Japanese authority, the meaning of Human Security was further expanded. In the report published by this commission entitled Human Security Now, it was mentioned that the concept of Human Security, in addition to emphasizing the two freedoms previously mentioned (freedom from want and 
freedom from fear), also implies "freedom to live with dignity". According to this report, "freedom to live with dignity" is related to empowerment, namely acknowledgment towards individual and community's significant role in caring for themselves from the various human security threats they encounter (Pitsuwan\& Caballero-Anthony, 2014). Therefore, Human Security is closely related to the development of human capabilities in dealing with change and uncertainty. Today the world community faces various uncertainties caused by climate change. Climate change is often seen as a stressor. This condition puts pressure on the earth resulting in drought, floods, or storms, which results in reduced human security, including loss of life or livelihood, or reduced availability of food and water. Therefore, individuals, communities, and communities need to have the ability to mitigate and adapt to this situation to protect their security (O'Brien and Leichenko, 2007; Purwanto\&Purba, 2017).

However, this concept had not yet been incorporated into the framework of security policy in Indonesia. Alexandra (2015), in her research, found that although some people in Indonesia generally understood the Human Security concept, no law in Indonesia specifically uses the term Human Security. There are efforts to include the concept of Human Security in the National Security Bill. It does mention the phrase 'Human Security', namely that national security consists of four types: human security, public security, internal security, and external security (Chapter 5). The meaning of human security is explained in the additional explanation section, namely the security of various types of problems, ranging from pandemic diseases, extreme hunger, natural disasters, poverty, crimes against humanity, and extreme stress. Nonetheless, this bill has not yet been passed by the Indonesian parliament.

On the other hand, in the 1945 Indonesian Constitution, although it does not explicitly use the term "Human Security", there are several articles that guarantee human security, for example, Article 28A on rights to life and to maintain life, which can be interpreted that everyone has the right to be protected from things that threaten his life or freedom from fear. Related to this issue, the Indonesian government has ratified the Act on Disaster Management 24/2007, which mentions efforts to build an 'early-warning system' to minimize the number of victims. In Chapter 6 of this law it is mentioned about the government's responsibility to implement disaster management, starting from reducing the risk of disasters and incorporating such risk reduction efforts into development programs, protecting the community from the effects of disasters, and meeting the needs of the community, including refugees suffering from the negative effects of disasters (Alexandra, 2015; Cuyugan, Agus, Dasig Jr., Nidea, Claricia, Taduyo, \& Camacho, 2017).

\section{Flood as a Source of Fear in Citarum River Basin}

Majalaya, as one of the Citarum river banks, is a district in the southeastern area of Bandung Regency, West Java Province, with an area of 2322.10 hectares divided into 11 villages, of which four villages are on the slopes (Neglasari, Wangisara, Padamulya, Biru) with altitude from sea level between 719-796 m. The rest, namely Sukamukti, Padaulun, Sukamaju, Majasetra, Majalaya, Majakerta, and Bojong Village, are in the plains with a height of sea level between 681-699 meters. The total population is 165,621 people (Indonesian Central Board for Statistics, 2018). The Citarum River, the longest and largest river in West Java Province, crosses this area. The headwaters of the river are in Wayang Mountain and Majalaya is located in the first $30 \mathrm{~km}$ from The Upper Citarum Watershed. Malayalam is in an area in the form of a giant basin that receives water from various tributaries of the Citarum. As a result of the reduced function of protected areas (forest and non-forest) in the upstream area, an increase in population along with the development of unplanned settlement areas as well as agricultural cropping patterns that are not suitable for critical land cause rain in mountainous areas to flow into the Citarum watershed and produce floods in the region (Muin, Boer, \&Suharnoto, 2015). Besides, the highly populated Majalaya District is also an industrial centre, especially a textile factory, so that the Citarum River becomes a place for the disposal of liquid and solid waste generated by the community and industry. This causes riverbed siltation, which is also a factor causing floods that occur every year in Majalaya (Suryana, Setiawan, \&Oktapian, 2018).

According to BNPB press release in 2019, in one year, residents on the banks of the Citarum River, especially residents in Baleendah and Majalaya Districts, Bandung Regency, could experience flooding ten times.

Floods in Majalaya usually occur in a relatively short time, where the water rises with a rapid flow so it is categorised as "banjirbandang" or flash flood (Junnaedhi et al., 2017). Classified as flash floods, they are typically short flood events in about six hours that are caused by heavy rains, broken dams, or broken embankments. The main character of flash floods is the rapid rise in river/ channel water levels. In the process of a flash flood event, it is usually preceded by a landslide triggered by rain and then followed by a flood. Floods like this have a high destructive power because, in addition to fast and swift water currents, they also carry heavy material (mud, stone, wood) which destroys houses and various infrastructures (including bridges and roads) which then have an impact on the isolated area flooding. Efforts to evacuate and distribute aid are difficult and expensive because of the damage to transportation lines. Also, along with the loss of houses and buildings, the community lost their livelihoods for quite a long period (Adi, 2013). 


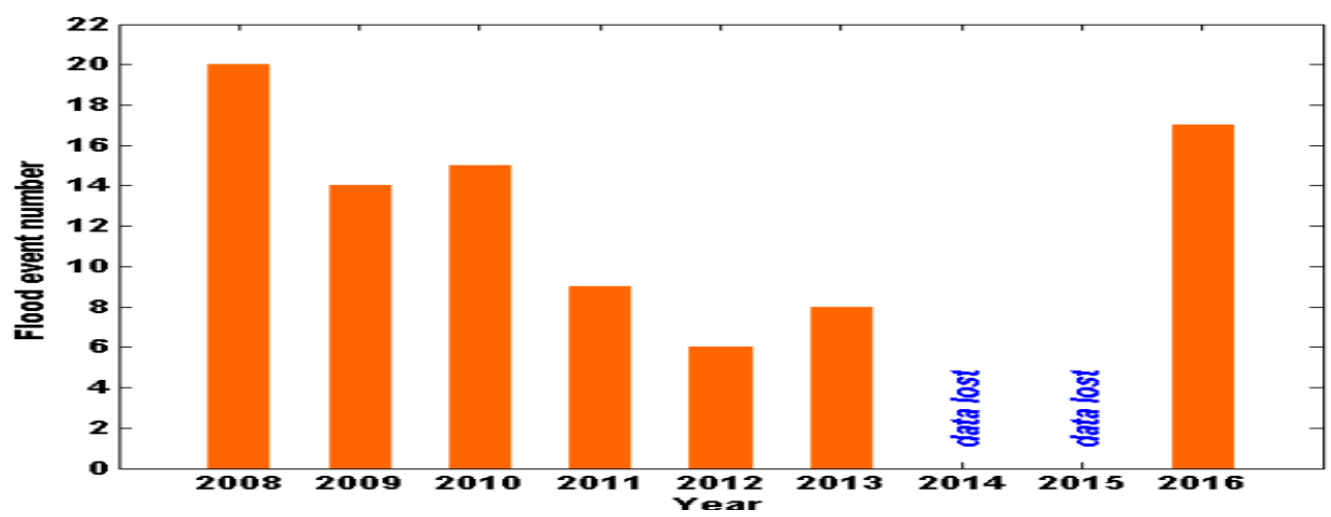

Figure 1: Flood Event in Majalaya District, Bandung Regency, Indonesia

Source: Junnaedhi et al. (2017)

The sudden arrival of floods made people afraid and worried. According to Riki Waskita, a Majalaya resident who pioneered community-based FEWS, he experienced flooding when he was five years old in 1982. At that time, floods only occurred once a year, but along with the increasing population and various other factors, floods occur more often. Every rainy season arrives, according to Riki, there is a 'psychological terror', which is a fear every time you see a dark cloud in the sky because it means that at times flood will come. Riki and his fellow Majalaya residents then learned, "... the pattern of duration, intensity, intensity, location of rain. The pattern is used to determine the origin of the overflow in the river around Majalaya" (Sharraz, 2019).

\section{Limited Efforts on Mitigating Disaster to Overcome the Threat}

The community formed by Riki was named 'JagaBalai' with the main activity being to monitor rainfall and water levels in the headwaters. When the water conditions are predicted to continue to improve and become flooded, the community will disseminate information and warnings to residents so they are prepared. With this early detection, residents have the opportunity to save their belongings or make other preparations to minimise flood damage.

Initially, JagaBalai spread information via Short Message Service (SMS) and along with the development of social media and the widespread use of smartphones, announcements were also made via an online application such as WhatsApp and Facebook. The following is an example of an announcement made on the JagaBalaiFanpage.

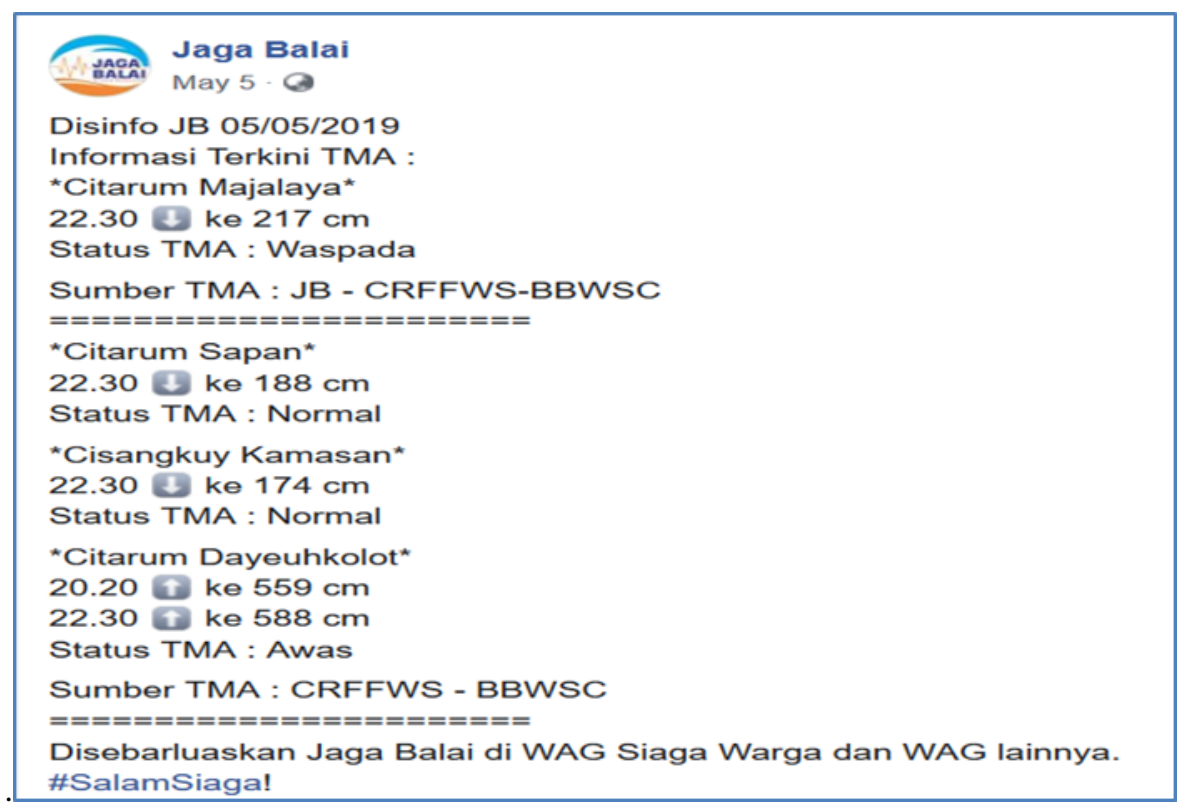

Figure 2: Example of an Announcement made by JagaBalai Community

Source: JagaBalaiFanpage on Facebook, posted on 5 May 2019 
JagaBalai also disseminates flood preparedness procedures as follows (translated from JagaBalaiFanpage, 2019):

* Appeal for Flood Preparedness \# *

The second rainy season in 2019 is approaching. Flooding is still vulnerable to head off. That is always the case with the data we have collected in the last ten years. Added to the flood events in various regions in Indonesia. Based on BNPB data for 2018, as many as 871 events out of a total of 2564 disaster events (dibi.bnpb.go.id \& kompas.com) as well as the potential for decreasing environmental carrying capacity in some parts of Bandung, we hope that a number of our notes may be of concern.

Revive vigilance for residents around flood-prone points. Some of them are the southeast sector of Majalaya, Paseh, and Ibun Districts. The eastern sector is Cicalengka, Rancaekek, Nibiru and the southern sector is the Banjaran District. Flash flooding type is also vulnerable to occur in these sectors, especially the southeast and east sectors.

High preparedness should also be carried out in the middle sector. Namely, flood-prone areas in the sub-districts of Baleendah, Dayeuhkolot, and Bojongsoang are still vulnerable to being submerged in water. We hope that the efforts being made by relevant government agencies this year in the CisangkuyBanjaran river and the Citarum tunnel around CurugJompong will have a significant impact on reducing events and water level if flooding in the middle sector still occurs.

Improve communication between the managers of their respective regions (sub-village). Coordination with relevant government institutions such as the Village Apparatus, District Leadership Coordination Forum, Village Forum, $B P B D$, Basarnas, and the Fire Service and Disaster Volunteer Teams from the disaster community/ humanitarian community must be carried out and be sustainable.

\section{METHODOLOGY}

Using the Human Security point of view, the article tries to show people's perspectives in defining security and overcoming threats, especially relating to flood in the Citarum river basin. As for the method, the research uses a qualitative approach with a study case as an analytical strategy. We interviewed some informants who live in Majalaya District and found secondary data from the government's and society's documents and analyze it by using the Human Security approach.

More specifically, this study uses qualitative methods to look in more detail at how the society perceives security and expresses fear, and at the same time anticipates the threat of disasters in a limited way as the formation of resilience. As one of the efforts to overcome fear due to the threat of flash floods in Majalaya, the surrounding society has established a community-based disaster mitigation system by establishing the JagaBalai community. In the midst of limitations, they empower all available capabilities in order to bring at least a sense of security and eliminate the worries that often infect the main community in each rainy season. We hope that this research contributes to the literature on Human Security concerns, especially those related to its elements of freedom of fear related to flood disasters.

\section{DISCUSSION/ANALYSIS}

The following is a guide to flood preparedness steps that can be done independently (translated from JagaBalaiFanpage, 2019):

\section{Household}

a. Note the loading and unloading embankments (containment boards) including leak-proof coating media (clay, cloth, newspapers, plastic bags, duct tape, waxes/wax) that are commonly available in their homes.

b. If the adhesive barriers use clay, make sure the clay is stored in a container - not a plastic bag/crackle - treated always in a moist condition (not wet or not dry).

c. Providing spheres of cloth/lap made from cotton shirts to cover the holes in the toilet drainage.

d. Houses that are accustomed to flooding the inside of the room are advised to provide/strengthen the paranggong (stage) both pairs and permanently.

e. It provides additional lighting such as flashlights with full batteries and emergency lights when there is a power outage when flooding (stored in a standby bag).

f. Secure important documents in a waterproof plastic bag.

g. Provide standby bags (drinking water, flashlights, medicines, blankets, instant food, change of clothes, important documents, please fill in the standby bags added in order of priority).

h. Move terminals/ electrical plugs and electronic goods to a place that is safer from the reach of a flood bath. 
i. Understand the stages of self-evacuation and the meeting point agreed in the community preparedness deliberations.

j. Also, monitor the development of the local upstream river whether through eye contact or follow the development of information from official government and disaster community accounts on social media.

k. Avoid hoaxes. Always ask the authorities.

\section{Sub-village(RT/RW) Management}

a. Prepare the latest operational scenarios for rescue and evacuation of affected residents to safe locations by understanding residents the understanding of safe houses and vulnerable homes from the results of participatory mapping that is always updated every six months in their respective areas.

b. Provide simple evacuation aids. For example, installing a guide rope/handle at the danger points to be passed during an evacuation in a flood situation from prone homes to safe houses.

c. Put an evacuation route sign to the safe house/ gathering point.

d. Install warning signs at dangerous locations (roads/alleys with holes, pointed objects, etc.).

e. Coordinate with local security apparatus/volunteer teams (such as; Community Protection, Tagana, Youth Organisation, Nature Lovers Group, Alert Flow Team, etc.) as a quick response team in self-evacuation priority priorities for vulnerable groups (toddlers, pregnant/breastfeeding mothers, people with needs specifically, the sick and the elderly) as well as residents who are in other dangerous conditions before the SAR team assistance arrives from outside the flooding scene.

f. Check and clean drains in the settlement.

g. Monitor the development of local weather upstream through direct visual vision or follow the development of information from official government or disaster community accounts on social media.

Since 2012, researchers from Bandung Institute of Technology have been working to create flood monitoring technology for use by the JagaBalai community and now they have 18 disaster prevention tools in the form of Automatic Weather Station (AWL) and Automatic Water Level Recorder (AWLR). The two devices are installed at vulnerable points to monitor clouds and water levels.

In their WhatsApp group, the JagaBalai community disseminates messages that usually consist of water level, weather, upstream, overflow potential, estimated overflow time, status level, status level information, and foundation jargon. The language used in the group is Sundanese (sub-nation of Indonesian) because the majority of Majalaya residents are Sundanese. This information is very important because when it rains with high intensity, the community only has 40 minutes to two hours before the flood current arrives in their area. However, this information must also be supported by the ability to deal with disasters, including the ability to save themselves and possessions, the ability to evacuate independently, and various other preparations because after the flooding occurs it is usually closed access to the area so that assistance from the government is difficult to enter. For this reason, JagaBalai also conducts various disaster simulation training in collaboration with various other communities.

A JagaBalai activist, Denni Hamdani wrote that all the preparations made by the community were meaningless without real support from the relevant agencies and the local government. According to him, the district leaders (district officer, districtlevel police, and district-level military command) must be able to play a more advanced role in anticipating all the worst possibilities due to the repeated floods that befall Majalaya (Hamdani, 2017). In his meeting with Ridwan Kamil, the candidate for governor of West Java (currently a governor), Hamdani criticised the government by saying, "Disaster management is still for aid and evacuation, whereas the Early Warning System (EWS) can save thousands of citizens." Hamdani also said that the government did not yet have a contingency plan and an emergency response plan (operational plan) in the face of disasters so that the community did both of them independently (Kunjana, 2018).

Besides, the government implemented policies that were counterproductive to flood prevention, through the issuance of the Indonesian Ministry of Environment's Decree Number 25the Year 2018. The decree contained a change in the main functions of forest areas from parts of the Kamojang Crater Nature Reservation (2,391 hectares) and Mount Papandayan Nature Reservation (1,991 hectares) become Nature Parks. JagaBalai community together with other communities who are members of the West Java Nature Reservation Alliance take action to reject this decree because the status reduction will disrupt ecosystems and increase the threat of natural disasters. According to Hamdani (2019), the Kamojang and Papandayan Nature Reservation areas are one of the headwaters of the Citarum River, reducing the status of the area will worsen the Majalaya flood. If Kamojang rains heavily, it only takes 45 minutes of the flood to reach Majalaya. According to Hamdani, instead of being made a tourist area, the nature reserve area should be restored to reduce the flood disaster. 
The asynchronous actions of the government with the knowledge of the Majalaya community were again seen in the implementation of the Citarum River normalization project which was carried out in June-August 2019. During the meeting of several community communities, including JagaBalai, various criticisms were raised regarding the normalisation project, including the concreting of riverbanks. According to Hamdani, concreting the riverbanks will make the Citarum river overflow water cannot be absorbed by the soil walls and the springs around the Cirtarum River cannot flow through the river in the dry season (Hidayat, 2019; Pramata, 2018).

In the perspective of Human Security, the flood is a threat to every individual, both in the form of psychological threats (feelings of fear and anxiety), as well as physical threats (loss of life and property). Thus, people affected by flooding, especially floods that have routinely come for decades, do not have freedom from fear and experience insecurity in the economic and environmental dimensions. JagaBalai as a community has played an important role in increasing the ability of citizens to mitigate and adapt to flood routines to protect their security. Flood early warning system is an important step to eliminate people's fears and give them the strength to prepare themselves for flooding.

The Indonesian government's commitment to protecting human security has been seen in the Disaster Management Act, which outlines the government's responsibility in carrying out disaster management, as well as protecting the public from the effects of disasters. In the National Medium Term Development Plan (Rencana Pembangunan Jangka Menengah Nasional or RPJMN) for 2015-2019 also included the conservation of natural resources and the environment and disaster management. In a special chapter related to management and reduction of disaster risks, three strategic directions are mentioned, namely disaster risk reduction in national and sub-national development frameworks, reducing vulnerability to disasters, and strengthening the capacity of governments, local governments, and communities in disaster risk reduction. The RPJMN also highlights the importance of strengthening risk information and early warning for disaster and climate risks (World Bank, 2016). However, an early warning system is not enough to provide freedom from fear to citizens. This is a form of adaptation to a major phenomenon that can only be overcome by the state, namely the destruction of ecosystems that have caused routine flooding many times a year for the last decades.

\section{CONCLUSION}

The fear that often arises from the threat of flash floods can be categorised as an existential threat, especially for human security. Research's findings in this paper show that environmental destruction caused by land conversion due to massive industrialization in the Citarum river basin plus the conversion of plantation land in the upstream area results in the potential for natural disasters in the form of flash floods which also adds to the list of sources of fear for society. The tendency of government, which does not consider local people's perspective in conceiving threat and fear in formulating security policy, becomes the main finding that strengthens our argument here. Amid the state's limitation in managing the environment, including disaster, a picture of the efforts of the people around Majalaya to mitigate disasters amid limitations by establishing a community-based early warning system called JagaBalai.

From this article, the community managed to anticipate the terror of fear of the threat of flooding by relying on information about the potential for flash floods in the Citarum River. The involvement of community participation independently in anticipating threats is an important finding in this study wherein general the country received more attention as the main source of security. Because residents have no other choice to anticipate threats coupled with consistent fear every rainy season, participation and volunteerism established in the JagaBalai community can be a source of security for residents, especially in the pre-disaster stage. Further research involving individual perspectives in understanding security has become important to do, especially in the issue of environmental safety and disaster.

\section{LIMITATION AND STUDY FORWARD}

This study has a few limitations as well. Firstly, the current research lacks discussion about the relation and dynamics between the perspective of individual and state as a source of security. Secondly, to increase the generalizability of the Human security approach, no respondents were limited.

The future study should involve what has been mentioned in the limitation here for more conclusive results.

\section{ACKNOWLEDGMENT}

The authors affirm that there is no conflict of interest in this article. In addition, no financial support is received for conducting this research. Thanks go to all people who have taken part in this study.

\section{AUTHORS CONTRIBUTION}

Arry Bainus carried out fieldwork and wrote the manuscript, Dina Yulianti helped in data cleaning and refined the write-up, while Luthfi Hamzah Husin carried out statistical analysis and helped in interpretation of the results. 


\section{REFERENCES}

1. Adi, S. (2013). Characterization of flash flood disaster in Indonesia. Indonesian Journal of Science and Technology, 15(1), 42-51.

2. Alexandra, L.A. (2015).Perception of Human Security: Indonesian View, in Human Security in Practice: East Asia Experiences JICA-RI Working Paper, No. 99. Tokyo: JICA Research Institute.

3. Aljazeera. (2018). Indonesia's most polluted river. https://www.aljazeera.com/programmes/101east 12018/05/indonesia-polluted-river-180502051143231.html

4. Bambals, R. (2015). Human security: An analytical tool for disaster perception research. Disaster Prevention and Management, 24 (2), 150-65. https://doi.org/10.1108/DPM-06-2014-0106

5. Cuyugan, A. B. S., Agus, G. E., Dasig Jr., D. D. Nidea, M. A., Claricia, E. E., Taduyo, M. A. B., \& Camacho, E. J. (2017). In aid of community policy and framework development: A sustainable integrated community advancement program. Journal of Advanced Research in Social Sciences and Humanities, 2(2), 87-95, https://doi.org/10.26500/JARSSH-02-2017-0202

6. Detiknews. (2018). Ribuanrumah di Majalaya, Ibun, danPasehterendambanjir(Thousands of Houses in Majalaya, Ibun, and Paseh are Flooded). https://news.detik.com/berita-jawa-barat/d-3882239/ribuan-rumah-di-majalaya-ibundan-paseh-bandung-terendam-banjir

7. Hamdani, D. (2017). SeandainyaBanjirBandangGarutTerjangMajalaya, SeberapaSiapkah Kita? (If the flood BandangGarut Lunge Majalaya, How ready are we?). https://www.balebandung.com/seandainya-banjir-bandanggarut-terjang-majalaya-seberapa-siapkah-kita/

8. Hamdani, D. (2019). BanjirBandangMenghantuiMajalayaJika SK 25 TidakDicabut(Flash floods haunt Majalaya if Decree 25 is not revoked). https://wartapalaindonesia.com/banjir-bandang-menghantui-majalaya-jika-sk25-tidakdicabut/

9. Hassani, W. (2016). Flood disaster risk analysis in Majalaya district, Bandung Regency (Unpublished master dissertation). Department of Geography Studies, UniversitasPendidikan Indonesia.

10. Hidayat, F. (2019). Dialog MasyarakatMajalayadengan BBWS CitarumTentangNormalisasiSingai CitarumBerjalanKondusif(Dialogue of Majalaya community with BBWS Citarum about normalization of Citarumriver running conductively). https://bandungside.com/2019/08/dialog-masyarakat-majalaya-dengan-bbwscitarum-tentang-normalisasi-sungai-citarum-berjalan-kondusif/

11. Indonesian Central Board of Statistics. (2018). MajalayadalamAngka 2018 (Majalaya District in Figures 2018). https://bandungkab.bps.go.id/publication/2018/09/26/8374839e8bcef227ba6b7b0e/kecamatan-majalaya-dalam-angka2018.html

12. JagaBalaiFanpage[JagaBalaiFanpage]. (2019). BanjirMajalaya(Majalaya's Flooding) [Facebook]. https://www.face book.com/jagabalai/photos/banjir-majalaya-22-23-feb-2018-sumber-1-hujan-area-ibun-dan-cikawao-durasi1-jam1507771089624141/

13. Jimba, M., Hubbard, S., Sase, E., Suzuki, T., and Otsuka, K. (2011). Human security approaches for disaster recovery and resilience. JMAJ, 54 (5), pp. 38-341, http://www.med.or.jp/english/journal/pdf/2011 05/338 341.pdf.

14. Junnaedhi, I, Riawan, E., Suwarman, R., Hadi, T. W., Lubis, A., Trilaksono, N. J. ... Setiawan, W. (2017). Majalaya flood early warning system: A community based aproach. IOP Conf. Ser.: Earth Environ. Sci.71, 1-12. https://doi.org/10.1088/1755-1315/71/1/012013

15. Kompas.com. (2019).Banjir di Kabupaten Bandung memaksaratusanwargamengungsi(Floods in Bandung Regency forced hundreds of residents to evacuate). https://regional.kompas.com/read/2019/03/08/05421901/banjir-dikabupaten-bandung-memaksa-ratusan-warga-mengungsi

16. Kontan.co.id. (2019).BNPB: WargaBaleendahdanMajalayaterkenabanjir 10 kali dalamsetahun(BNPB: Baleendah and Majalaya residents affected by flood 10 times a year). Retrieved from:https://regional.kontan.co.id/news/bnpbwarga-baleendah-dan-majalaya-terkena-banjir-10-kali-dalam-setahun. (Accessed 20 September 2019).

17. Kunjana, G. (2018). Penangananbanjircitarummasihbersifat sporadic (Citarum flood management still sporadic). https://investor.id/archive/penanganan-banjir-citarum-masih-bersifat-sporadi.s

18. Martin, M. \& Owen, T (ed). (2014). Routledge Handbook of Human Security. Oxon: Routledge. https://doi.org/10.4324/9781315885926

19. Muin, S. F., Boer, R., \&Suharnoto, Y. (2015). Flood modeling and analysis of losses due to flood disasters in the Upper Citarum watershed.Jurnal Tanah danIkliim, Vol 39 (2),

20. O'Brien, K. \&Leichenko, R. (2007). Human security, vulnerability, and sustainable adaptation (Human Development Report 2007/2008). New York, NY: UNDP.

21. Pitsuwan, S. and Caballero-Anthony, M. (2014). Human Security in Southeast Asia: 20 years in Review. Asian Journal of Peacebuilding, 2(2), 199-215, http://hdl.handle.net/10371/93637.

22. Pramata, A. (2018). Citarum flood management still sporadic. https://merahputih.com/post/read/penanganan-banjircitarum-masih-bersifat-sporadis 
23. Purwanto\&Purba, C. S. (2017). Legal aid compliance for poor local community. Journal of Advanced Research in Social Sciences and Humanities, 2(6), 363-370. https://doi.org/10.26500/JARSSH-02-2017-0604

24. Sato, J. (2010). Matching goods and people: Aid and human security after he 2004 tsunami. Development in Practice, 20(1), 70-84. https://doi.org/10.1080/09614520903436943

25. Sharraz. (2019). Hujan yang MenerorMajalaya(The rain is terrorizing Majalaya). http://www.fixindonesia.com/hujanyang-meneror-majalaya/

26. Sriboonyaponrat, P. (2016). The implementation process of the public policy to promote and develop the quality of life of the disabled in Thailand as carried out by the ministry of social development and human security. International Journal of Humanities, Arts and Social Sciences, 2(6), 198-202. https://doi.org/10.20469/ijhss.2.20001-6

27. Suryana, Setiawan, A., \&Oktapiana, S. (2018). Flood mitigation by the community in Bojong village, Majalaya district, Bandung Regency. Geoarea/JurnalGeografi, 1(2), 54-64.

28. The Diplomat. 'Indonesia's citarum: The world's most polluted river'. https://thediplomat.com/2018/04/indonesiascitarum-the-worlds-most-polluted-river/

29. UNDP. (1994). Human development report. http://hdr.undp.org/sites/default/files/repo rts/255/hdr_1994_e n_complete_nostats.pdf

30. Wibowo, P., \&Zamzamy, A. (2015). Failed state and threats to human security. International Journal of Humanities, Arts and Social Sciences, 1(4), 140-146. https://doi.org/10.20469/ijhss.20002-4

31. World Bank. (2016). Building Indonesia's resilience to disaster: Experiences from mainstreaming disaster risk reduction in Indonesia program. http://documents.worldbank.org/curated/en/318951507036249300/pdf/106245REVISED-PUBLIC-Building-Indonesia-s-Resilience-to-Disaster.pdf 